PERM JOURNAL OF PETROLEUM AND MINING ENGINEERING

ВЕСТНИК ПНИПУ. ГЕОЛОГИЯ. НЕФТЕЕАЗОВОЕ И ГОРНОЕ ДЕЛО

ISSN 2224-9923

Volume / ToM 16 №4 2017

http://vestnik:pstu.ru/geo/

УДК 553.632:622.232+622.363:622.235

Article / Статья

(C) PNRPU / ПНИПУ, 2017

\title{
JUSTIFICATION ON SAFE PARAMETERS OF DRILLING AND BLASTING MINING OF SYLVINITE FORMATIONS OF UNCONVENTIONAL THICKNESS TOGETHER WITH CONTINUOUS MINING OF CONVENTIONAL FORMATIONS IN THE MINES OF VERKHNEKAMSKOE FIELD OF POTASSIUM AND MAGNESIUM SALTS
}

\section{Sergey S. Andreyko, Valentin M. Mal'tsev, Vladimir V. Anikin ${ }^{1}$, Sergey Ya. Zhikharev ${ }^{1}$}

Perm National Research Polytechnic University (29 Komsomolskiy av., Perm, Russian Federation, 614990)

${ }^{1}$ Mining Institute of the Ural Branch of the Russian Academy of Sciences (78 Sibirskaya st., Building A, Perm, 614007, Russian Federation)

\section{ОБОСНОВАНИЕ БЕЗОПАСНЫХ ПАРАМЕТРОВ БУРОВЗРЫВНОЙ ОТРАБОТКИ СИЛЬВИНИТОВЫХ ПЛАСТОВ НЕКОНДИЦИОННОЙ МОЩНОСТИ СОВМЕСТНО С КОМБАЙНОВОЙ ВЫЕМКОЙ КОНДИЦИОННЫХ ПЛАСТОВ НА РУДНИКАХ ВЕРХНЕКАМСКОГО МЕСТОРОЖДЕНИЯ КАЛИЙНО-МАГНИЕВЫХ СОЛЕЙ}

\author{
С.С. Андрейко, В.М. Мальцев, В.В. Аникин ${ }^{1}$, С.Я. Жихарев ${ }^{1}$
}

Пермский национальный исследовательский политехнический университет (614990, Россия, г. Пермь, Комсомольский пр., 29) ${ }^{1}$ Горный институт Уральского отделения Российской академии наук (614007, Россия, г. Пермь, ул. Сибирская, 78a)

Received / Получена: 21.08.2017. Accepted / Принята: 10.10.2017. Published / Опубликована: 01.12.2017

Key words:

potash mine, sylvinite formation, unconventional thickness, drilling and blasting mining, industrial safety, inter-chamber block loading level, interlayer roof, cading level, interlayer cleaning chamber, design parameters, explosive charge, explosion pulse, seismic explosion impact, critical vibration rate, fracture radius.

\begin{abstract}
In the conditions of the Verkhnekamskoe field of potassium and magnesium salts unconventional in terms of thickness sylvinite seams are involved in the mining. That requires methodological support and new technological solutions. One of the possible directions in the excavation of sylvinite seams of unconventional thickness is the use of drilling and blasting. A method for calculating the safe geomechanical parameters of the chamber development pattern was developed in order to justify the possibility of drilling and blasting excavation of sylvinite seams of the chamber development pattern was developed in order to justify the possibility of drilling and blasting excavation of sylvinite seams
of unconventional thickness. The paper presents theoretical calculations for determination of the parameters of a chamber development pattern of unconventional thickness. The paper presents theoretical calculations for determination of the parameters of a chamber development pattern
taking into account the requirements of current regulatory documents. That ensures geomechanical safety during drilling and blasting mining taking into account the requirements of current regulatory documents. That ensures geomechanical safety during drilling and blasting mining
of sylvinite seams of unconventional thickness as well as during mining of sylvinite seams of unconventional thickness in combination with of sylvinite seams of unconventional thickness as well as during mining of sylvinite seams of unconventional thickness in combination with
mashinery mining of seams with conventional thickness. Two options of drilling and blasting mining of sylvinite layers depending on the mashinery mining of seams with conventional thickness. Two options of drilling and blasting mining of sylvinite layers depending on the mining and geological conditions of development, are considered in the paper. The first option considers drilling and blasting excavation by
the chamber pattern of one sylvinite seam of unconventional thickness. The second option considers drilling and blasting mining of an the chamber pattern of one sylvinite seam of unconventional thickness. The second option considers drilling and blasting mining of an
unconventional sylvinite reservoir together with a machinery mining of adjacent sylvinite layers that have conventional thickness. Minimum unconventional sylvinite reservoir together with a machinery mining of adjacent sylvinite layers that have conventional thickness. Minimum
allowable size of the production chamber in the drilling and blasting mining of sylvinite seams of unconventional thickness, design and actual parameters of chambers and inter-chamber blocks are justified according to the requirements of regulatory documents. The procedure for calculation of sizes of the cleaning chambers in drilling and blasting mining and inter-chamber blocks in the joint excavation of sylvinite layers of conventional and unconventional thickness. The method for determination of safe parameters of blasting operations providing the permissible value of the fracturing zone in the soil and roof of the cleaning chambers mined by the drilling and blasting method is presented. Calculations have been performed to determine the fracture radius based on the calculation of explosion pulse and dynamic strength of the salt rocks. Determination of the allowable weight of explosion is done using the value of the displacement speed of the particles in the array. As a result of the studies performed, the safe parameters of drilling and blasting mining of one sylvinite layer with unconventional thickness by the chamber pattern and the sylvinite formation of unconventional thickness together with longwall machinery mining of conventional formation at the mines of Verkhnekamskoe field of potassium and magnesium salts.
\end{abstract}

Ключевые слова: калийный рудник, сильвинитовый пласт, некондиционная мощность, буровзрывная выемка, технологическая безопасность, междукамерный целик, степень нагружения, релк, стень нагружения, очистная камера расчетнне параметры, заряд взрывчатого вещества, импульс взрыва, сейсмическое воздействие взрыва, критическая скорость колебаний, радиус колебаний, радиус
В условиях Верхнекамского месторождения калийно-магниевых солей в отработку вовлекаются сильвинитовые пласты, не кондиционные по мощности, что требует методического обеспечения и новых технологических решений. Одним из возможных направлений в технологии выемки сильвинитовых пластов некондиционной мощности является применение буровзрывной выемки. Для обоснования возможности буровзрывной выемки сильвинитовых пластов некондиционной мошности разработана методика расчета безопасных геомеханических параметров камерной системы разработки. В статье приводятся теоретические расчеты для определения параметров камерной системы разработки с учетом требований действуюших нормативных документов, обеспечивающие геомеханическую безопасность при буровзрывной выемке сильвинитовых пластов некондиционной мошности, а также при выемке сильвинитовых пластов некондиционной моцности совместно с комбайновой отработкой рабочих пластов, . имеющ кондици у варй

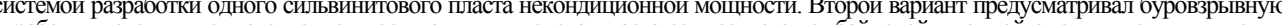
(1) д

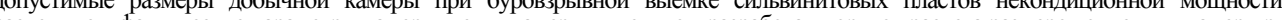
расчетные и фактиеские параметры камер и междукамерных целиков, разработан порядок расчета размеров очистных камер при буровзрывной выемке и междукамерных целиков при совместной выемке сильвинитовых пластов кондиционной и некондиционной мощности. Представлена методика определения безопасных параметров взрывных работ, обеспечивающих допустимую величину зоны трещиноватости в почве и кровле очистных камер, отрабатываемых буровзрывным способом. Выполнены расчеты по определению величины радиуса трещиноватости на основе учета импульса взрыва и динамической прочности соляных пород. Определение допустимой массы взрыва производится по величине скорости смещения частиц массива. В результате выполненных исследований обоснованы безопасные параметры буровзрывной отработки одного сильвинитового пласта некондиционной мощности камерной системой разработки, а также сильвинитового пласта некондиционной мощности совместно с комбайновой выемкой кондиционных пластов на рудниках Верхнекамского месторождения калийно-магниевых солей.

Sergey S. Andreyko (Author ID in Scopus: 55922205900, 6506180352) - Doctor of Engineering, Professor, Head of the Department of Development of Mineral Recourses Valentin M. Mal'tsev (Author ID in Scopus: 7102941853) - PhD in Engineering, Associate Professor at the Department of Development of Mineral Recourses Fields (tel.: +007342 2198031 , e-mail: vmmal@bk.ru)

Vladimir V. Anikin (Author ID in Scopus: 54894082000) - PhD in Engineering, Research Fellow (tel.: +007 342 216 37 03, e-mail: anikin@mi-perm.ru). Sergey Ya. Zhikharev - Doctor of Engineering, Research Fellow (mob. tel.: +007342 21658 42, e-mail: perevoloki55@mail.ru).

Андрейко Сергей Семенович - доктор технических наук, профессор, заведующий кафедрой разработки месторождений полезных ископаемых (тел.: +007 3422198438 ,

е-mail: ssa@mi-perm.ru). Контактное лицо для переписки.

Аникин Владимир Васильевич - кандидат технических наук, научный сотрудник (тел.: +007 342 216 37 03, e-mail: anikin@mi-perm.ru). 


\section{Introduction}

Today there is a general trend for complication of conditions of occurrence and reduction of conditions of obtaining minerals during the underground mining of mineral deposits.

One of the complicating factors in the extraction of potassium ores from the Verkhnekamskoe field of potassium and magnesium salts (VFPMS) is the presence of significant areas of minefields on which unconventional in terms of thickness productive formation lies. For example, production formation of $\mathrm{AB}$ sylvinite composition approximately for $20-30 \%$ of the area of occurrence within the minefield of the BKPRU-4 mine of Uralkali PJSC have has an unconventional thickness (less than 2 $\mathrm{m})$ with rich content of the useful component $(\mathrm{KCl}$ content up to $40 \%$ ).

Today two main methods are of practical importance for the extraction of potassium formations of unconventional thickness such as combine and drilling \& blasting.

During combine method of mining the formations of unconventional thickness it is most expedient to use combines with an adjustable drumtype executive organ. With all the obvious advantages of this type of combines (the ability to seize formations of various thicknesses and high productivity), it also has its drawbacks, the main ones of which are: heavy dustiness of working zones in the extraction of potash ores and high cost of an import mining complex [1-13].

Use of mining-and-roadheading machine of Ural-type that are the main ones in the preparation and development of formation at the VKFPMS, during the removal of unconventional thickness leads to a strong dilution of potash ore due to considerable cutting of the enclosing rock salt formations as the combines of this type have a constant (for each standard size) cross-section.

An alternative to the combine machine is the drilling \& blasting method of mining of unconventional formations. Obvious advantages of this method are the possibility of mining of potassium formations of various thicknesses and folding, almost with no diluting, use of conventional ways of ventilating the face with regular means with help of fans of local airing, relatively low cost of domestic equipment and explosive materials.

It should be noted that, depending on the mining and geological conditions there are two options for using the drilling and blasting method:
1) drilling \& blasting of a single formation with unconventional thickness;

2) drilling \& blasting mining of unconventional thickness together with a combine machine of adjacent potash formations having the conditioning power.

Due to the relatively low thickness of the waterproofing layer (WPL) and complex mining and geological conditions at the Verkhnekamskoe field of potassium and magnesium salts, a chamber system of development is used to maintain the roof on relatively "rigid" interchamber toe (ICT) that do not allow sharp dislocations of overlying rocks, and panel or panel-block methods of preparing the mine field with a direct or reverse order of excavation.

Drilling and blasting method proposed for the extraction of sylvinite formations of unconventional thickness allows to use the methods of preparation used in the potash mines and chamber system of development without any changes.

\section{Problem statement}

In order to determine the safe parameters of drilling \& blasting excavation of unconventional sylvinite seams, it is necessary to solve the following problems:

- to determine for geomechanical security the width of the inter-chamber toe and dimensions of cross section of cleaning chamber, under which the degree of loading of the ICT will not exceed the permissible value;

- determine the mass of the explosive charge to ensure technological safety on the basis of an assessment of the harmful effect of blasting on the elements of the chamber development system with the indicated parameters of the treatment chamber, which, with the required granulometric composition of the broken sylvinite ore, produces a minimal destructive effect on the ICT and interplastic, i.e. when the estimated width of the broken edge part does not exceed the allowable value.

\section{The calculation procedure \\ for safe geomechanical parameters during drilling \& blasting of unconventional in terms of thickness sylvinite formations}

Safe parameters for drilling \& blasting of a single sylvinite formation of substandard capacity were calculated as given next. At the first stage, the crosssectional area of the production drilling \& blasting chamber was determined. Taking into account the 
experience of drilling and exploratory production of sylvinite formations used at the Verkhnekamskoe field in previous years, it is proposed to use a rectangular cross section for production. So, in order to find the bottom area $\mathrm{S}_{1}, \mathrm{~m}^{2}$, it is necessary to know the width of the cleaning chamber and extractable thickness $[14,15]$ :

$$
S_{1}=a_{1 s} \cdot m_{1}
$$

where $a_{1 s}-$ design value of the width of the treatment chamber, $\mathrm{m} ; m_{1}$ - calculated value of the extractable thickness during drilling \& blasting testing of an unconventional sylvinite formation, $\mathrm{m}$.

The minimum design value of the width of a cleaning chamber $a_{1 s}$ is determined based on dimensions of the mobile drilling and transport equipment, as well as the requirements of the current regulatory documents. According to that documents there must be gaps of at least $1.2 \mathrm{~m}$ side of the passage for people and $0.5 \mathrm{~m}$ from the opposite side in the shafts intended for transportation of ore and communications with cleaning faces [16].

Thus, the required minimum design (actual) value of the width of the cleaning chamber of rectangular cross-section, $\mathrm{m}$, will be

$$
a_{1 s}=1.2+d+0.5=1.7+d,
$$

where $d$-maximum width of used drilling, load or transport equipment, $m$.

The height of a shaft above the free passage for people should be at least $1.8 \mathrm{~m}$ along its entire length [16].

Consequently, in case of drilling and blasting of sylvinite seams of unconventional thickness, the minimum value of the height of the cleaning chamber of rectangular section $\mathrm{H}_{1 \text { min }}$ must satisfy the condition [16]

$$
H_{1 \min } \geq h_{1}+\Delta h_{1} \geq 1.8
$$

where $h_{1}$ - maximum height of the equipment used (drilling, load or transport), $\mathrm{m} ; \Delta h_{1}-$ distance from the most protruding part of the machine to the roof of the mine, $\Delta h_{1}=0.5 \mathrm{~m}$.

Depending on the ratio of geological thickness of unconventional formation $\left(m_{\text {form }}\right)$ and minimum permissible height of the applied technological equipment $\left(H_{1 \mathrm{~min}}\right)$ three values of the extractable thickness are possible:

1) $m_{\text {form }} \geq H_{1 \text { min. }}$. If such is the case, drilling and blasting of the formation is carried out for the full thickness, while the estimated extractable thickness, $\mathrm{m}$, is

$$
m_{1}=m_{\mathrm{T}}
$$

wherr $m_{\mathrm{T}}-$ technological thickness of the formation, $\mathrm{m}$.

Technological thickness of the formation, $\mathrm{m}$, is determined from expression

$$
m_{\mathrm{T}}=m_{\text {form }}+m_{\text {cake }},
$$

where $m_{\text {form }}-$ geological thickness of unconventional sylvinite formation, $\mathrm{m}$; $m_{\text {cake }}-$ thickness of the "cake", m (taken into account at technological necessity of "cake" undermining);

2) $m_{\text {form }}<H_{1 \min }$. In this case, it is necessary to perform a joint drilling and blasting operation of the potash reservoir for the full thickness, with cutting of the layer of the overlying (or underluing) rock salt formation to produce a shaft with a height of $H_{1 \mathrm{~min}}$, which enables people to work and move the drilling and handling equipment.

3) $m_{\text {form }} \ll H_{1 \min }$. In this case, to prevent dilution at very low reservoir thicknesses (for example at $\left.m_{\text {form }}<0,5 H_{1 \mathrm{~min}}\right)$ it is necessary to provide a two-layer selective drilling and blasting mining and here two options are possible. In the first option, if it is advisable to cut the layer of rock salt of the underlying formation by the mining conditions, then the first (within a single entry) mined formation is the low-thicknesses sylvinite layer for the full thickness. Then the chamber height is brought to the required value of $H_{1 \text { min }}$ by mining the calculated thickness layer from the underlying rock salt reservoir, its shipment and storage within the mining section. In the second option, if it is advisable to cut the layer from rock salt of an overlying layer according to mining conditions, then the first layer (within one bluff) is mined taking into account required design thickness, then the salt is shipped and stored within the mining area, after which the underlying lowthickness sylvinite formation is mined for the full thckness and height of the chamber is also brought to the required value $H_{1 \text { min }}$.

The boundary of the transition from the gross to selective can be determined on the basis of calculation of the average content of the useful component in the mined rock mass, which satisfies the conditions accepted in the mine.

For the second and third options, the estimated extractable power, $\mathrm{m}$, is

$$
m_{1}=m_{\mathrm{T}}+\Delta m_{\mathrm{rs}}=H_{1 \mathrm{~min}},
$$

where $\Delta m_{\mathrm{rs}}-$ value of the cutting formation of rock salt from the adjacent formation, determined with considered required production height $H_{1 \text { min }}$. 
The value of the formation of rock salt to be cut, $\mathrm{m}$, from the adjacent formation, is determined from the equation

$$
\Delta m_{\mathrm{rs}}=\left(h_{1}+\Delta h_{1}\right)-m_{\mathrm{T}}=H_{1 \min }-m_{\mathrm{T}} .
$$

The width of chambers and inter-chamber toes during drilling and blasting of a single sylvinite formation of unconventional thickness was determined in accordance with the design scheme shown in the Fig. $a$.

In order to determine the degree of loading $\mathrm{C}$ using adopted parameters of a development system in areas with use of drilling and blasting operations the design width of the interchamber toe should be reduced by an amount of $2 \Delta b_{1}=1.0 \mathrm{~m} \mathrm{[14]:}$

$$
b_{1}=b_{1 s}-2 \Delta b_{1},
$$

where $b_{1}$ - design width of the inter-chamber toe, $\mathrm{m} ; b_{1 s}$ - design (actual) width of the inter-chamber toe, $\mathrm{m} ; \Delta b_{1}$ - width of the weakened (due to drilling and blasting operations) marginal zone of the ICT, $\Delta b_{1}=0.5 \mathrm{~m}$.

Parameter $\mathrm{C}$ taking into account formula (8) the interaxial distance $11, \mathrm{~m}$, equals to

$$
\begin{gathered}
l_{1}=2\left(0.5 a_{1 s}\right)+b_{1 s}=a_{1 s}+b_{1 s}= \\
=\left(a_{1 s}+2 \Delta b_{1}\right)+\left(b_{1 s}-2 \Delta b_{1}\right)=a_{1}+b_{1},
\end{gathered}
$$

where $a_{1 s}$ and $b_{1 s}$ - design (actual) values of the width, respectively, of the drilling and blasting chamber and ICT, taking into account two weakened edge zones, used for working, $\mathrm{m} ; a_{1}$ and $b_{1}$ - design width, respectively, of drilling and blasting chamber and ICT, used when the ICT loading degree is found, $\mathrm{m}$.

Thus, taking into account expressions (2) and (9), calculated (minimum) width of the treatment chamber, $\mathrm{m}$, is

$$
\begin{aligned}
a_{1}= & a_{1 s}+2 \Delta b_{1}=1.7+d+2 \Delta b_{1}= \\
& =1.7+d+1.0=2.7+d .
\end{aligned}
$$

designed (actual) value of the width of the ICT, m, taking into account expression (8) is equal to

$$
b_{1 s}=b_{1}+2 \Delta b_{1}=b_{1}+1,0 .
$$

The design (actual) values of the widths of the chambers and ICT $\left(a_{1 s}, b_{1 s}\right)$, indicated in formulas (2) and (11), should be used when extracting a low-thickness sylvinite formation by a drilling and blasting method, i.e. when conducting cleaning works.

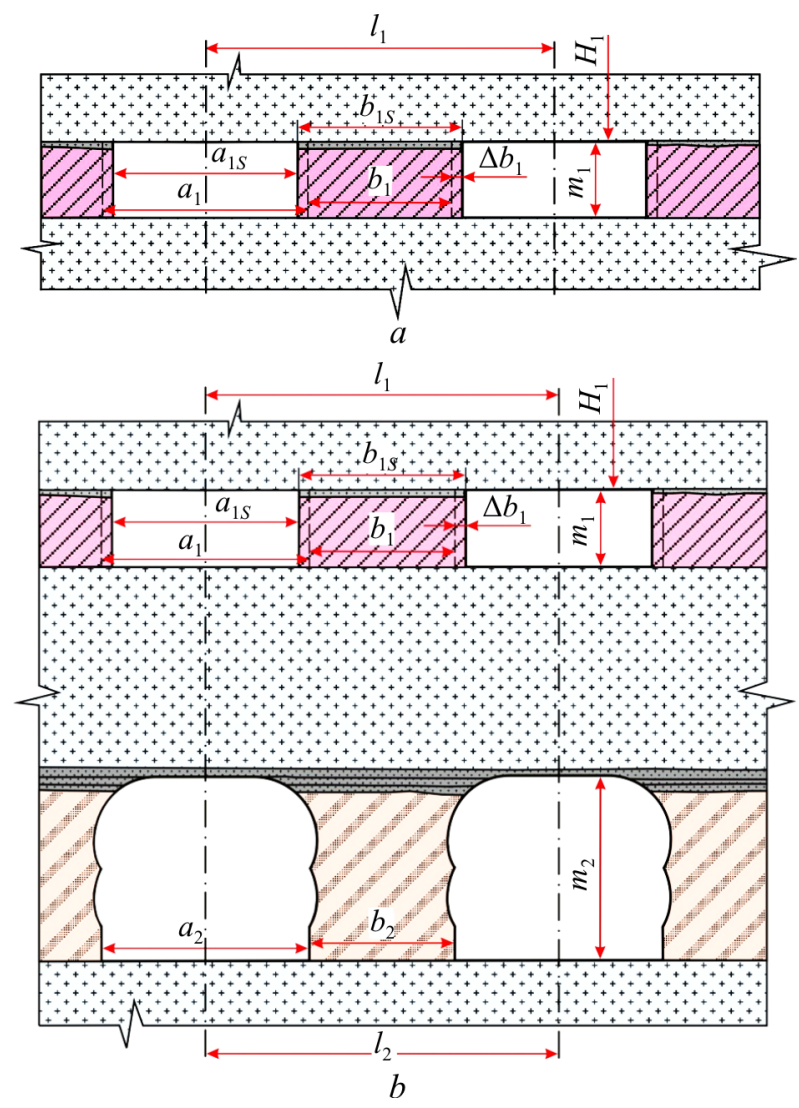

Fig. Calculation scheme for determination of the parameters of a chamber development system for drilling and blasting mining of a single sylvinite formation of unconventional thickness $(a)$ and joint mining by drilling, blasting and longwall machinery mining $(b): H_{1}$ - the maximum value of the distance from the earth's surface to the top of a toe in a section of development pattern, $\mathrm{m} ; b_{1 s}-$ design (actual) width of the inter-chamber toe (taking into account two weakened edge zones), $\mathrm{m} ; \Delta b_{1}$ - weakened edge area of inter-chamber toe, $\mathrm{m} ; a_{1 s}$ - design (actual) width of the drilling and blasting chamber, $\mathrm{m} ; a_{1}$-design value of width of the cleaning drilling and blasting chamber, $\mathrm{m} ; b_{1}-$ design width of the inter-chamber toe, $\mathrm{m}$; $l_{1}$ - inter-axial distance, $\mathrm{m} ; m_{1}-$ calculated extracted thickness of a low-yield sylvinite formation, $\mathrm{m}$; $a_{2}$ - the width of the chamber on the working layer along the soil (with one-pass minig is equal to the width of the combine used), $\mathrm{m} ; b_{2}-$ width of the ICT for soil on the main working formation, $\mathrm{m} ; l_{2}$ - interaxial distance on the main working formation, $\mathrm{m}$; $m_{2}$ - extractable thickness of the main sylvinite working formation, $\mathrm{m}$

Having the design width of the cleaning chambers $\left(a_{1}\right)$ and normative loading degree [C], the calculated width of inter-chamber toe during the mining of sylvinite formation with no hydraulic backfilling of cleaning chambers is found by the formula [14] 


$$
b_{1}=p_{m}\left(p_{0}+\sqrt{p_{0}^{2}+\frac{2 a_{1}}{p_{m}}}\right) .
$$

The parameters $p_{\mathrm{m}}, \mathrm{p}_{0}$ are determined by formulas

$$
p_{m}=\frac{m \cdot \lambda_{p}}{2 \beta_{o} \cdot \beta_{m}} ; p_{o}=1-\frac{\beta_{o}}{\lambda_{p}} ; \lambda_{p}=\frac{\lambda_{o}}{[C]} ;
$$

where $m$ - design height of inter-chamber toe, $\mathrm{m}$; $\beta_{o}$ and $\beta_{m}-$ approximation parameters: $\beta_{o}=0.654$; $\beta_{m}=1.06 ; \lambda_{o}-$ parameter characterizing mining and technical conditions.

The calculated height of inter-chamber toe, $m$, $\mathrm{m}$, for extraction of sylvinite layers with no hydraulic filling of the cleaning chambers is found by formula [14]

$$
m=m_{0}+\Delta m,
$$

where $m_{0}$ - extracted formation thickness, $\mathrm{m} ; \Delta m-$ possible increment of the toe, $\mathrm{m}$.

It is necessary to take the calculated value of the extractable thickness in the formula (14) $m_{0}=m_{1}$, which is defined taking into account expressions (4)-(6).

The calculated increment of the heights $\Delta m$ will be [14]

$$
\Delta m=\left\{\begin{array}{l}
\Delta m_{o}, \\
m_{o k}
\end{array} .\right.
$$

The parameter $\Delta \mathrm{mo}$ is determined by the formula

$$
\Delta m_{o}=\beta_{o k}\left(a-a_{o m}\right)
$$

where $\beta_{o k}$ - coefficient that takes into account the effect of stability of roof of chambers on the magnitude of the increment in the calculated height of the toe; $a$ - estimated width of the chamber, in this case the value $a=a_{1}$ is defined by expression (10), $\mathrm{m} ; a_{o m}$ - stable roof space of chambers, m; $m_{o k}$ - thickness of the cakes left in the roof of chambers when extracting an unconventional thickness formation, $\mathrm{m}$.

If the sylvinite formation of unconventional thickness is taken out with a "cake", then in the formula (15) $m_{o k}=0$.

Coefficient $\beta_{o k}$ is determined from the equation [14]

$$
\beta_{o k}=0.7\left[1.0-\beta_{o m} \sqrt{a_{o m}}\right] \text {, }
$$

where $\beta_{\text {om }}$ - approximation parameter, $\beta_{\text {om }}=0.262$;

Mining and technical conditions for extracting the sylvinite formation are characterized by the parameter $\lambda_{o}[14]$ :

$$
\lambda_{o}=\xi \frac{\gamma \cdot H_{1}}{\sigma_{o m}},
$$

where $\xi$ - coefficient that takes into account change in load on the toe due to the influence of mining and technical factors; $\gamma$ - bulk weight of overburden thickness of rocks $\left(\gamma=2.2 \mathrm{tf} / \mathrm{m}^{3}\right) ; H_{1}$ - the maximum value of the distance from the earth's surface to the top of a toe in a section of development pattern, $\mathrm{m} ; \sigma_{\text {om }}-$ aggregate strength of rocks in an array within the design height of inter-chamber toe $m$, t.

The coefficient that takes into account change in load at the ICT due to the influence of mining and technical factors, is found by the formula [14]

$$
\xi=\xi_{1} \cdot \xi_{2} \cdot \xi_{x},
$$

where $\xi_{1}$ - coefficient that takes into account the impact of man-made load, $\xi_{1} \geq 1.0 ; \xi_{2}$ - coefficient taking into account the influence of the reference pressure, $\xi_{2} \geq 1.0 ; \xi_{x}$ - coefficient that takes into account the influence of inter-passage toe, $\xi_{x}=1.0$.

Values of the coefficients $\xi_{1}, \xi_{2}$ calculated for specific mining and geological conditions in accordance with the requirements [14].

Aggregate strength of rocks in an array within the design height of inter-chamber toe is determined from expression

$$
\sigma_{o m}=k_{o} \cdot \sigma_{o}=k_{m} \cdot k_{c} \cdot k_{l},
$$

where $\sigma_{o}$ - equivalent (reduced) strength of rocks composing the toe; $k_{m}$ - coefficient that takes into account the influence of the scale factor, $k_{m}=1.12$; $k_{c}$ - coefficient that takes into account the influence of clay interlayers; $k_{l}$-coefficient that takes into account the effect of cutting tape toe, $k_{l}=1.25$.

The coefficient that takes into account the influence of clay interlayers, is calculated by the formula

$$
\begin{gathered}
k_{c}=\left\{\begin{array}{l}
\alpha_{c}\left(1+\beta_{c} \sqrt{0.05-\delta_{c}}\right) \\
\alpha_{c}\left(1-\beta_{c} \sqrt{\delta_{c}-0.05}\right)
\end{array}\right. \\
\left\{\begin{array}{c}
0 \leq \delta_{c} \leq 0.05, \\
0.05<\delta_{c} \leq 0.35,
\end{array}\right.
\end{gathered}
$$

where $\alpha_{c}=0.86 ; \beta_{c}=0.7281 ; \delta_{c}-$ relative content of clay interlayers.

The value $\delta_{c}$ is calculated by the formula

$$
\delta_{c}=\frac{1}{m} \sum_{i=1}^{n} \delta_{c i} \cdot m_{i}
$$


where $\delta_{c i}$ - relative content of clay interlayers in the $i$-th formation of $m_{i}$ thickness.

Equivalent strength of rocks, $\mathrm{tf} / \mathrm{m}^{2}$, is determined by the formula

$$
\sigma_{o}=\frac{m}{\sum_{i=1}^{n} m_{i} / \sigma_{c i}}
$$

where $m_{i}$ - thickness of the $\mathrm{i}$-th formation of the rock $(i=1,2,3 \ldots) ; n$ - the number of different in strength rocks composing the ICT within their design height $m$; $\sigma_{c i}$ - design compressive strength of standard samples of the i-th layer of the rock, $\mathrm{tf} / \mathrm{m}^{2}$.

When using the drilling and explosive method of extraction, the estimated degree of loading of ICT $\left(C_{1}\right)$, taking into account adopted parameters of the development system (see the figure), is determined by the formula

$$
C_{1}=\frac{\lambda_{o} \cdot l_{1}}{\left(b_{1 s}-2 \Delta b_{1}\right) k_{f}},
$$

where $k_{f}-$ a shape factor determined from expression

$$
k_{f}=\left\{\begin{array} { l } 
{ \sqrt { 2 \lambda _ { m } } } \\
{ \beta _ { o } ( 1 + \beta _ { m } \cdot \lambda _ { m } ) }
\end{array} \text { at } \left\{\begin{array}{l}
0<\lambda_{m}<0.5 \\
\lambda_{m} \geq 0.5
\end{array}\right.\right.
$$

The parameter $\lambda_{m}$ is found by the formula

$$
\lambda_{m}=\frac{b_{1}}{m} \text {. }
$$

Parameters of the development system must ensure the fulfillment of the following condition [14]:

$$
V_{m 1} \leq\left[V_{m 1}\right]
$$

where $V_{m 1}$ - the design value of the maximum deflection of the WPL layers, corresponding to the accepted parameters of extracting of a thin layer, $\mathrm{m}$; $\left[V_{m 1}\right]$ - the value of allowable deflection of WPL layers in mining and geological conditions od study, $m$.

Determination of the width of chambers and inter-chamber toe during drilling and blasting of unconventional thickness of a sylvinite layer, together with lonwall machinery of adjacent potassium layers of conventional thickness, was carried in the way described below.

During calculation of parameters of extraction of and more layers, it is necessary to assess the proximity of two adjacent layers and to determine estimated thickness of the inter-layer toe for the adjacent layers of the cap pillar mr. In this case, extarction of adjacent layers is carried out by coaxial chambers from the top down, ahead of the front of the cleaning works on an upper layer at least $50 \mathrm{~m}$.

There are two options possible depending on the value of the estimated thickness $m_{r}$ when the seams are close:

1) $m_{r}<\left[m_{r}\right]$, m;

2) $m_{r} \geq\left[m_{r}\right]$, m.

The permissible thickness of the interlayer cap pillar [mr] for sylvinite layers is found from the expression

$$
\left[m_{r}\right]=\left\{\begin{array} { l } 
{ 1 . 5 } \\
{ \beta _ { r } \cdot a _ { m } ^ { a _ { r } } }
\end{array} \text { at } \left\{\begin{array}{l}
3.2 \leq a_{m} \leq 5.5 \mathrm{~m}, \\
a_{m} \geq 5.5 \mathrm{~m} .
\end{array}\right.\right.
$$

The values of the approximation parameters in formula (28) are: $\beta_{r}=0.356 ; a_{r}=0.844$.

If $m_{r}<\left[m_{r}\right]$ the parameters of a chamber system for extraction of two close layers are determined both when a single layer is taken with extractable thickness $m_{o}$ equal to the calculated height of the goaf space during the extraction of two layers $M_{o}[14]$.

Two options are possible depending on the position of a sylvinite layer of unconventional thickness in relation to the main extracteble layer:

1. If a thin layer lies below the formation of conventional thickness, then during the first run of the combine an extractble layer is worked out for the full thickness, then the interlayer space is recovered, the stone salt is transported and stored within the mining area, after which during the last run of the combine unconventional formation is extracted.

If the interlayer space has a small thickness then joint mining of the interlayer space and thin layer is possible. It should be noted that if such is the case then it is not advisable to use a drilling and blasting extraction.

2. If a thin layer lies above the extractded one, then the upper low-strength sylvinite layer is extracted first by drilling and blasting method and, if necessary, part of the interlayer space (minimum height of the stroke has to be at least $1.8 \mathrm{~m}$ ). Then the interlayer space (or its remaining part) is excavated. Transportation and storage of rock salt are carried out within the mining area, after which the combine is used to extract bottom layer fot the full thickness.

In case of small thickness (especially if the total thickness of the layer and interlayer does not exceed $1.8 \mathrm{~m}$ ), it can be extracted together with a lowthickness layer using the drilling and blasting method. 
The second option considers that design width of the chamber $a_{1}$, used in determination of the width of the ICT on a low-density formation, must be greater than the design (actual) one $a_{1 s}$ by a value of $2 \Delta b_{1}=1.0 \mathrm{~m}$. Here, in case of single-pass chambers it is necessary to take the width of the combine path $a_{k}(\mathrm{~m})$ as a design width

$$
a_{1}=a_{k}+2 \Delta b_{1}=a_{k}+1.0 \text {. }
$$

The design (actual) value of the chamber width $a_{1 s}(\mathrm{~m})$ must satisfy the following condition:

$$
a_{1 s}=a_{k} \geq 1.7+d .
$$

For type I chambers the width of the combine path, $\mathrm{m}$, is determined at the soil level:

$$
a_{k}=a_{o} .
$$

For type II chambers, the maximum width of chambers is taken, $\mathrm{m}$ :

$$
a_{k}=a_{m} .
$$

The type of the chamber is determined on the basis of requirements taking into account specific mining and technical conditions and parameters of extraction [14]. Having the design thickness of the inter-layer pillar $m_{r} \geq\left[m_{r}\right]$ extraction parameters are found separately for each layer. Calculation of safe geomechanical parameters of drilling and blasting chambers should be carried out only after determining the parameters of excavation of the main extracted by the combine method strata. Determination of the calculated width of the treatment chamber on a low-power formation, extracted by the drilling and blasting method, is proposed for joint mining with extracted layer by the combine method through the following scheme (see Fig. $b$ ).

The calculation is carried out in the following sequence. First, the design width of the ICT on the main extracted layer is determined, with the interaxial distance $(\mathrm{m})$ equal to

$$
l_{2}=a_{2}+b_{2},
$$

where $a_{2}$ - the width of the chamber on the main extracted layer (in case of one-way mining it is equal to the width of the used combine), $\mathrm{m} ; b_{2}-$ width of the ICT in the main extracted layer, $\mathrm{m}$.

In case of coaxial chambers the interaxial distance on a low-thickness formation $(\mathrm{m})$ is equal to

$$
l_{1}=a_{1}+b_{1}=l_{2}
$$

where $a_{1}$ - estimated width of the chamber on a low-thickness formation, $\mathrm{m} ; b_{1}$ - estimated width of ICT on a low-thickness formation, $\mathrm{m}$.

First, the calculated width of the camera $a_{1}$ is defined based on condition (10), while the estimated width of the beam $b_{1}(\mathrm{~m})$ will be

$$
b_{1}=l_{2}-a_{1} \text {. }
$$

Taking into account the expressions (24)-(26) and the initial value of the chamber width $a_{1}$, the estimated loading level of the ICT $C_{1}$ during the extraction of a thin layer will be equal to

$$
C_{1}=\frac{\lambda_{o} \cdot l_{1}}{\left(b_{1 s}-2 \Delta b_{1}\right) k_{f}}=\frac{\lambda_{o} \cdot l_{2}}{b_{1} \cdot k_{f}}
$$

Then, by changing the calculated width of the chamber $a_{1}$, it is necessary to find the optimal design width of the ICT on a low-thickness layer $b_{\text {lopt, }}$ at which the calculated loading degree does not exceed the allowable value for specific mininggeological conditions [14]:

$$
C_{1} \leq\left[C_{1}\right] .
$$

The design (actual) value of the width of the cleaning BVR chamber $(\mathrm{m})$, taking into account expression (10), will be

$$
a_{1 s}=a_{1 \mathrm{opt}}-2 \Delta b_{1} \geq 1.7+d .
$$

The design (actual) value of the ICT width on a low-thickness formation (m), with the expression (11) taken into account, is equal to

$$
b_{1 s}=b_{1 \mathrm{opt}}+2 \Delta b_{1} .
$$

Parameters of the development system during the excavation of two sylvinite layers should ensure that the condition

$$
V_{m 1.2} \leq\left[V_{m}\right],
$$

where $V_{m 1.2}$ - a calculated value of the maximum deflection of the layers of the WPL caused by the development of two layers, determined from expression

$$
V_{m 1.2}=V_{\text {exc1 }}+V_{\text {exc2 }},
$$

where $V_{o m 1}-$ a calculated value WPL the maximum deflection of the layers of the WPL caused by development of two layers, determined from expression; $V_{\text {om } 2}-$ a calculated value of the maximum deflection of the layers of the WPL caused by development of the main extrected layer, $\mathrm{m}$. 


\section{Method for calculation of safety parameters of blasting operations during the drilling \& blasting extraction of unconventional thickness sylvinite layers}

Calculation of the radius $\mathrm{Rm}$ of cracking caused by the blasting of an elongated charge is performed using a technique in which a lateral pressure pulse $J$ $(r)$ of the detonation products of an explosive damps with distance $r$ and gets at the initial moment of explosion the value $J(0)$ when $r=0$ [17-39].

The change in the moment with distance is determined by the dependence

$$
J(r)=\pi \cdot d_{s} \cdot L_{s} \cdot P(r) \cdot t(r) .
$$

In this case, pressure and time of action of the pressure of detonation products of the explosive are determined from expressions

$$
\begin{gathered}
P(r)=P_{1} /(1+k \cdot r)^{m}, \\
t(r)=r_{0}[a+b(r-1)] 10^{-3},
\end{gathered}
$$

where $k, m, a, b-$ empirical coefficients; $r_{0}$ - charge radius, $\mathrm{m} ; r$ - relative distance from the center of the charge, expressed in the radii of the charge: $r=R / r_{o}, R$-distance, $\mathrm{m} ; P(r)$ - pressure at a distance $r, \mathrm{~Pa} ; t-49 / 5000$ duration of pressure at a distance $r, \mathrm{~Pa} ; d_{s}, L_{s}$ - diameter and length of the hole (borehole).

Initial mean pressure in the charging cavity is given by

$$
P_{1}=0.25 \rho_{\mathrm{e}} \cdot D^{2}\left(d_{s} / d_{z}\right)^{-6},
$$

where $\rho_{\mathrm{e}}-$ density of explosive charge, $\mathrm{kg} / \mathrm{m}^{3}$; $D$ - velocity of detonation of explosive charge, $\mathrm{m} / \mathrm{s}$; $d_{z}$ - explosion diameter (of the bullet), $\mathrm{m}$.

The relationship between pressure and volume of gases at the time of blasting due to its large magnitude (of the order of $5 \mathrm{GPa}$ ) is determined not by the Boyle-Mariotte law, but by a power dependence of the form

$$
P \cdot V^{\gamma}=\text { const, }
$$

where $\gamma \approx 3$.

Increase in the volume of charge gases when they expand to the walls of the charging cavity is proportional to the square of the ratio of the diameters $\sim\left(d_{s} / d_{z}\right)^{2}$. Taking into account (45), the decrease in pressure $P_{1}$ with an increase in volume (in the third degree) will be proportional to the ratio of diameters to the 6th power: $2(-\gamma) \approx-6$.
It is proposed to calculate fracture radius $R_{m}$ by the value of the reduced radius $R_{t}=R_{m} / r_{o}$ through the empirical equation (46) by the method of successive approximations:

$$
R_{t}=J\left(R_{t}\right)^{0.9} / J_{i}^{0.6}
$$

where $J\left(R_{t}\right)$ - impulse with $r=R_{t} ; J_{i}$ - impulse criterion of dynamic strength (for sylvinite $J_{i}=7300 \mathrm{H} \cdot \mathrm{c} / \mathbf{i}^{2}$, where $i-$ degree of crushing of the blasted rock mass), $i=W / d_{k} ; W$ - line of least resistance of exploded charge, $\mathrm{m}$; $d_{k}$ - the second diameter of a piece of blown rock mass, $\mathrm{m}$.

Initial value $R_{t 0}$ is given from physical considerations on the basis of known experimental data of similar conditions. Based on such a defined value the impulse is determined $J_{1}\left(R_{t 0}\right)$, is substituted into the formula (46), and obtain the value $R_{t 1}$. Then the values are compared $R_{t 0}$ and $R_{t 1}$.

If $R_{t 0}$ is less than the obtained value of $R_{t 1}$, then it is is increased to $R_{t 01}$ and according to the described procedure, $\mathrm{R}_{t 2}$ is obtained, again it is compared with $R_{t 01}$. Usually, 3-4 approximations are sufficient to satisfy equality $R_{t 0 n}=R_{t(n+1)}$ with an accuracy of 2-3 decimal places.

The radius of crack formation in meters is calculated by the formula $R_{m}=r_{o} \cdot R_{t 0 n}$ and rounded to 1-2 decimals.

The value of the initial pulse $J(0)$ is controlled by the value of the initial pulse $J_{o}$ :

$$
J_{o}=k \cdot M \cdot D \cdot L_{z} / d_{z},
$$

where $k$ - calculated-empirical coefficient; $M-$ mass charge of explosive, $\mathrm{kg} ; D$ - detonation velocity of charge explosive, $\mathrm{m} / \mathrm{s} ; L_{z}, d_{z}$ - length and diameter of explosive charge, $\mathrm{m} ; K_{z}-$ charge factor, $K_{z}=L_{z} / L ; k=I \cdot 0.817$.

From that:

$$
\begin{gathered}
I=0.375 K_{z}\left(1+2 K_{z}\right)- \\
-0.1875\left(1-K_{z}\right)^{2} \ln \frac{1+K_{z}}{1-K_{z}} .
\end{gathered}
$$

It is assumed that at a distance of $R_{m}$ (or more) the cracking of the rock no longer occurs. Thus, the cracking radius $R_{m}$ is the maximum radius of destruction of the array of the primary straight by the explosion compression wave.

When using a safety explosive type ammonite PGV-20 with blasting parameters $d_{s}=0.042 \mathrm{~m}$, $r_{o}=0,021 \mathrm{~m}, d_{z}=0.036 \mathrm{~m}$, with charge density 
$\rho=1050 \mathrm{~kg} / \mathrm{m}^{3}, L_{z}=2.5 \mathrm{~m}, L=3 \mathrm{~m}$, length of face $0,5 \mathrm{~m}$, charge weight $M=2.67 \mathrm{~kg}$ relative dimensionless maximum fracture radius will be $R_{t}=28.57$ and cracking radius $R_{m}=0,6 \mathrm{~m}$.

For contour holes that are located at a height of $0.2 \mathrm{~m}$ from the soil of the formation, such a cracking radius in the joint excavation of two layers is prohibited due to the restriction of the zone of propagation of cracks in the soil in magnitude of $0.2 \mathrm{~m}$ [14]. Therefore, contour holes in the soil of the cleaning chamber should create a zone of rocks no more than $0.4 \mathrm{~m}$. To fulfill this condition, the mass of the explosive of their charge in accordance with the calculations for the above formulas should not be more than $1.8 \mathrm{~kg}$, which will ensure $\mathrm{R}_{m}=0.39 \mathrm{~m}$. The length of such a charge is $1.8 \mathrm{~m}$. Taking into account the minimum permissible length of the face, the length of the hole under these conditions will be $2.3 \mathrm{~m}$ [40].

Thus, it should be noted that the calculations presented allow us to propose two options for drilling and blasting of sylvinite seams of unconventional thickness.

In the first option, when excavating one layer of unconventional thickness by the drilling and blasting method, it is recommended to use holes up to $3.0 \mathrm{~m}$ in length, while the mass of the explosive in the hole is $2.67 \mathrm{~kg}$ and cracking zone does not exceed $0.6 \mathrm{~m}$. Since the contour holes are located at a distance of not less than 0.1-0.2 $\mathrm{m}$ from the outline, the fracturing zone behind the contour will be $0.4-0.5 \mathrm{~m}$, which corresponds to the requirements of normative documents [14].

In the second option of excavation of layers, when removing seams of unconventional thickness by drilling and blasting, together with extraction of conventional thickness layers, it is necessary to use shorter blastholes with a length of no more than $2.3 \mathrm{~m}$. The mass of the explosive in the hole will be $1.8 \mathrm{~kg}$ and the cracking zone will not exceed $0.39 \mathrm{~m}$. In this case, when the contour holes are located at a distance of $0.2 \mathrm{~cm}$ from the extracted contour, the fracturing zone behind the outline (including in the mine floor) does not exceed $0.19 \mathrm{~m}$, which also meets the requirements of regulatory documents [14].

The value of the fracture radius $R_{m}, \mathrm{~m}$, is calculated by the formula

$$
R_{m}=0.241 A^{0.35} \cdot q^{0.45} \cdot \sigma_{\text {comp }}^{-0.8} \cdot L^{-0.5},
$$

where $A=\rho \cdot C^{2}, \rho-$ rock density, $\mathrm{kg} / \mathrm{m}^{3}$ $\left(\rho=2100 \mathrm{~kg} / \mathrm{m}^{3}\right), C$ - speed of sound in the rock,
$\mathrm{m}(C=4500 \mathrm{~m} / \mathrm{s}) ; q-$ explosive energy per 1 meter of charge, $\mathrm{J}, q=M_{1} \cdot Q_{v}\left(M_{1}=1.069 \mathrm{~kg} / \mathrm{m}\right.$, $\left.Q_{v}=3.4 \cdot 10^{6} \mathrm{~J}\right) ; \sigma_{\text {comp }}=250 \cdot 10^{5} \mathrm{~Pa}$.

With the parameters specified explosion for explosive mass charges, respectively $M_{1}=2.67 \mathrm{~kg}$ and $M_{2}=1.8 \mathrm{~kg}$ radii of crack formation will be $R_{1 m}=0.79 \mathrm{~m}$ and $R_{2 m}=0.43 \mathrm{~m}$. Thus, formula (49) gives higher fracture radius values with respect to formula (46). This is caused by the use of different strength criteria in them. In formula (49), the traditional static index is used such as compressive strength in a standard sample. In formula (46), a dynamic index is used, which takes into account the intensity of fragmentation of the sample upon its destruction.

Determination of the allowable mass of the explosion, safe from the effect on the interchamber lobbies and soil of excavation is made from the value of the displacement velocity of the particles of the massif (mass velocity) not exceeding the critical displacement velocity for a given rock [33], $\mathrm{cm} / \mathrm{s}$ :

$V_{\mathrm{cr}}=\frac{37.5\left(C_{p}^{2}-4 C_{z}^{2} / 3\right)\left\{[1+e(1-2 \mu)]^{\frac{8}{3}}-1\right\}}{C_{p}[1+e(1-2 \mu)]^{4}}$,

where $C_{p}$ - velocity of longitudinal oscillations, $\mathrm{m} / \mathrm{s} ; C_{z}-$ velocity of transverse vibrations, $\mathrm{m} / \mathrm{s} ; \mu-$ Poisson's ratio; $e$ - ultimate deformation of rock.

Mass velocity at the specified distance $R_{c}=R / M^{0.333}, \mathrm{~cm} / \mathrm{s}$, looks like [33]

$$
V=235000\left(C_{p} \cdot \rho \cdot t\right)^{-0,5} \cdot R_{c}^{-n},
$$

where $\rho$ - rock density, $\mathrm{kg} / \mathrm{m}^{3} ; t$ - period of natural oscillation, ms; $n$ - degree of attenuation of velocity with distance $(1.5<n<2)$.

Expression $235000\left(C_{p} \cdot \rho \cdot t\right)^{-0.5}$ is the coefficient $K$ of a particular rock in the formula of the canonical form $V=K \cdot R_{c}^{-n}$.

The admissible mass of the explosion is determined by formula (52), derived from expression (51):

$$
M_{\mathrm{ad}}=R^{3}\left(\frac{V}{K}\right)^{3 / n}
$$

Using formula (52), the distance $R$ is measured from the center of the explosion of the set of holes before the start of the protected zone, i.e. practically up to the walls of the working in the 
given direction. The zone of cracks behind the safety loop $R$ is created by the extreme (contouring) holes of the set, the value of which is calculated by formulas (46) and (49). The zones of fractring from inner holes are smaller than the distance between the series of holes and therefore do not affect the crack formation during the detonation of the drilling holes.

\section{Conclusion}

Study to justify the safety parameters of drilling and blasting method of extraction of sylvinite layers of unconventional thickness together with combine harvesting of conventional layers in the mines of the Verkhnekamskoe field of potassium-magnesium salts allow to draw the conclusions given below.

1. It is established that during drilling and blasting of unconventional thickness formations the minimum design width of the cleaning chamber should be increased by $1.7 \mathrm{~m}$ in comparison with the maximum overall width of the used drilling, loading or transport equipment. Calculated width of the cleaning chamber, taking into account the fracture zone from drilling and blasting operations, should be increased by $1.0 \mathrm{~m}$ in comparison with the design value, and the minimum height of the mine should be not less than $1.8 \mathrm{~m}$.

2. It is established that at the design thickness of the interlayer pillars of lower than permissible value it is advisable to use a drilling and blasting pit of unconventional thickness when the formation is not unconventional in thickness above the layer of conditioning power.

3. It is established that with the design value of the interlayer pillar, which exceeds the minimum permissible value, the parameters of excavation of unconventional in thickness formation are determined only after calculations of the parameters of conventional layer.

4. One of the options to find the width of the ICT on an unconventional reservoir, which is expressed as the difference between the interaxial distance and width of the chamber on a conventional layer, is the method of selecting the optimum chamber width at which the ICT loading level is equal to the permissible value.

5. It is found that in case of drilling and explosive excavation of a sylvinite layer with unconventional thickness, the fracture radius, determined on basis of the calculation of explosion pulse and dynamic strength of rocks, does not exceed $0.6 \mathrm{~m}$. During the joint extraction of sylvinite layer of unconventional thickness by drilling and blasting method and sylvinite layer of conventional thickness by combining method, the fracture radius does not exceed $0.39 \mathrm{~m}$. At the same time, the safe mass of the explosive charge is determined taking into account the mass velocity.

\section{References}

1. Zil'bershmidt V.G. et al. Tekhnologiia razrabotki kaliinykh rud [Technology for the development of potash ores]. Moscow, Nedra, 1977, 287 p.

2. Chelpanova E.V., Koshurnikov N.S. O vozmozhnosti razrabotki malomoshchnykh plastov Verkhnekamskogo mestorozhdeniia kaliinykh solei [On the possibility of developing low-capacity strata of the Verkhnekamskoe potassium salt deposit]. Izvestiia vuzov. Gornyi zhurnal, 2004, no.5, pp.6-9.

3. Shvab R.G., Tsygankov S.N., Deshkovskii V.N. Perspektivy razvitiia kaliinoi promyshlennosti V Respublike Belarus' [Prospects for the development of the potash industry in the Republic of Belarus]. Gornaia mekhanika, 2005, no.3, pp.84-88.

4. Starkov L.I., Zemskov A.N., Kondrashev P.I. Razvitie mekhanizirovannoi razrabotki kaliinykh rud [Development of mechanized development of potash ores]. Perm', Izdatel'stvo Permskogo gosudarstvennogo tekhnicheskogo universiteta, 2007, $522 \mathrm{p}$.

5. Semenov V.V., Mal'cher M.A., Petrov V.P. Rossiiskie prokhodchesko-ochistnye kombainy dlia dobychi kaliinoi rudy i kamennoi soli [Russian sinkcleaning combines for the extraction of potassium ore and rock salt]. Gliukauf, 2007, no.1, pp.31-33.
6. Novikov A. Oborudovanie firmy DBT dlia kamernostolbovoi sistemy razrabotki i prokhodki vyrabotok [DBT equipment for chamber-pillar development and excavation]. Gliukauf, 2007, no.1, pp.44-49.

7. Smychnik A.D., Morev A.B., Vas'ko M.V. Sistemy razrabotki kaliinykh mestorozhdenii: tekhnologicheskie skhemy, oborudovanie, effektivnost' [Systems for the development of potash deposits: technological schemes, equipment, efficiency]. Gornaia mekhanika, 2008, no.4, pp.16-28.

8. Benzen Kh. Kaliinaia promyshlennost' Germanii [The potash industry in Germany]. Gliukauf, 2009, no.1, pp.27-30.

9. Morev A.B., Smychnik A.D., Kazachenko G.V. Gornye mashiny dlia kaliinykh rudnikov [Mining machines for potash mines]. Minsk, Integralpoligraf, 2009, 544 p.

10. Metodicheskoe rukovodstvo po vedeniiu gornykh rabot na rudnikakh OAO "Sil'vinit" [Methodological guidelines for mining operations at the mines of OJSC Silvinit]. Novosibirsk, Nauka, 2011, 487 p.

11. Solov'ev V.A., Konstantinova S.A., Alymenko D.N., Spekhov L.M. Osobennosti razrabotki kraevykh chastei Verkhnekamskogo kaliinogo mestorozhdeniia [Features of the development of the marginal parts of the Verkhnekamsk potash deposit]. Gornyi zhurnal, 2011, no.12, pp.41-45. 
12. Isaevich A.G. Snizhenie zapylennosti atmosfery rabochei zony pri rabote kombainovogo kompleksa $\mathrm{s}$ barabannym ispolnitel'nym organom [Reduction of dustiness in the atmosphere of the working area during the operation of the combine complex with a drum-type executive]. Strategiia i protsessy osvoeniia georesursov. Sbornik nauchnykh trudov. Perm', Gornyi institut Ural'skogo otdeleniia Rossiiskoi akademii nauk, 2015, iss.13, pp.264-266.

13. Isaevich A.G. Aktual'nye voprosy organizatsii provetrivaniia tupikovykh vyrabotok [Topical issues of organization of winding dead-end workings]. Strategiia $i$ protsessy osvoeniia georesursov. Sbornik nauchnykh trudov. Perm', Gornyi institut Ural'skogo otdeleniia Rossiiskoi akademii nauk, 2016, iss.14, pp.266-268.

14. Ukazaniia po zashchite rudnikov ot zatopleniia i okhrane podrabatyvaemykh ob"ektov na Verkhnekamskogo mestorozhdeniia kaliinykh solei [Guidelines for the protection of mines from flooding and protection of work-in-process facilities at the Verkhnekamsk deposit of potassium salts]. Saint Petersbug, Perm, Berezniki, 2014, 130 p.

15. Metodicheskie rekomendatsii $\mathrm{k}$ "Ukazaniiam po zashchite rudnikov ot zatopleniia i okhrane podrabatyvaemykh ob"ektov na Verkhnekamskogo mestorozhdeniia kaliinykh solei" [Methodical recommendations to the "Guidelines for the protection of mines from flooding and protection of work-worn objects at the Verkhnekamsk deposit of potassium salts"]. Saint Petersbug, Perm, Berezniki, 2014, 66 p.

16. Pravila bezopasnosti pri vedenii gornykh rabot $i$ pererabotke tverdykh poleznykh iskopaemykh [Safety rules for mining and processing of solid minerals]. Federal'nye normy i pravila $\mathrm{v}$ oblasti promyshlennoi bezopasnosti no.32935. Moscow, ZAO NTTs PB, 2015, iss. $78,273 \mathrm{p}$.

17. Rukovodstvo po vedeniiu vzryvnykh rabot na kaliinykh rudnikakh Verkhnekamskogo mestorozhdeniia [Guidelines for blasting operations at the potash mines of the Verkhnekamskoye deposit]. Perm', 1984, 195 p.

18. Mal'tsev V.M., Shablovskii V.P. Eksperimental'nye issledovaniia treshchinoobrazovaniia $\mathrm{v}$ solianykh porodakh pri vzryve odinochnogo shpurovogo zariada vzryvchatogo veshchestva na dve obnazhennye poverkhnosti [Experimental studies of crack formation in salt rocks during the explosion of a single blasting charge of an explosive on two exposed surfaces]. Razrabotka solianykh mestorozhdenii. Mezhvuzovskii sbornik nauchnykh trudov. Perm', 1983, pp.95-98.

19. Bezmaternykh V.A., Lykhin P.A., Leshchukov N.N., Mal'tsev V.M. Opredelenie parametrov komplekta shpurovykh zariadov vzryvchatykh veshchestv [Determining the parameters of a set of blasting charges of explosives]. Fizikotekhnicheskie problemy razrabotki poleznykh iskopaemykh, 1975, no.6, pp.69-73.

20. Bandis S.C., Lumsden A.C., Barton N.R. Fundamentals of rock joint deformation. International Journal of Rock Mechanics and Mining Sciences \& Geomechanics Abstracts, 1983, vol.20, no.6, pp.248-268. DOI: 10.1016/0148-9062(83)90595-8

21. Barton N., Bandis S., Bakhtar K. Strength, deformation and conductivity coupling of rock joints.
International Journal of Rock Mechanics and Mining Sciences \& Geomechanics Abstracts, 1985, vol.22, no.3, pp.121-140. DOI: 10.1016/0148-9062(85)93227-9

22. Bungum H., Mykkeltveit S., Kvaerna T. Seismic noise in Fennoscandia with emphasis on hight frequencies. Bulletin of the Seismological Society of America, 1985, vol.75, no.6, pp.1489-1513.

23. Pyrak-Nolte L.J., Myer L.R., Cook N.G.V. Transmission of seismic waves across singl natural fractures. Journal of Geophysical Research: Solid Earth, 1990, vol.95, no.B6, pp.8617-8638. DOI: 10.1029/JB095iB06p08617

24. Gu b., Nihei K.T., Myer L.R., Pyrak-Nolte L.J. Fracture interface waves. Journal of Geophysical Research: Solid Earth, 1996, vol.191, no.1, pp.827-835. DOI: 10.1029/95JB02846

25. Kricak L. et al. Development of a fuzzy model for predicting the penetration rate of tricone rotary blasthole drilling in open pit mines. Journal of the Southern African Institute of Mining and Metallurgy, 2015, no.115(11), pp.1065-1071.

26. Hatherly P. et al. Drill monitoring results reveal geological conditions in blasthole drilling. International Journal of Rock Mechanics and Mining Sciences, 2015, no.78, pp.144-154. DOI: 10.1016/j.ijrmms.2015.05.006

27. Servet D. Variation of vertical and horizontal drilling rates depending on some rock properties in the marble quarries. International Journal of Mining Science and Technology, 2014, no.24 (2), pp.269-273. DOI: 10.1016/j.ijmst.2014.01.020

28. Gerhardt H.-P. et al. Anforderungen an die genauigkeit der Zündzeiten elektrischer sprengzünder und versuche zur ermittlung des einflusses des verzögerungsintervalls auf das sprengergebnis. Kali und Steinsalz, 2013, heft 1, pp.20-29.

29. Behnsen H., Krüger D. Kongressbericht zur 29. Bergtechnischen tagung 2013 in Hannover. Kali und Steinsalz, 2013, heft 2, pp.10-15.

30. Steinhage M., Triebel R. Arbeitsplatzgrenzwerte: gesundheitsschutz der arbeitnehmer verbessern und die wettbewerbsfähigkeit der industrie wahren. Kali und Steinsalz, 2014, heft 3, pp.6-13.

31. Lykhin P.A., Mal'tsev V.M. Normirovannyi impul's drobleniia kak pokazatel' drobimosti gornykh porod [The normalized impulse of crushing as an index of the crushing of rocks]. Fizicheskie problemy razrusheniia massivov gornykh porod. Sbornik dokladov mezhdunarodnoi konferentsii. Moscow, Rossiiskaia akademiia nauk, 1999, pp.174-176.

32. Lykhin P.A., Mal'tsev V.M. Chastnyi zakon impul'sa razrusheniia gornykh porod svobodnym udarom [Private law of the impulse of rock destruction by free impact]. Izvestiia vuzov. Gornyi zhurnal, 2001, no.1, pp.53-55.

33. Mal'tsev V.M., Andreiko S.S. Metod rascheta tsilindricheskogo vruba s uchetom velichiny koeffitsienta razrykhleniia vzryvaemoi porody [Method for calculating a cylindrical cut with allowance for the value of the coefficient of loosening of the explosive rock]. Izvestiia vuzov. Gornyi zhurnal, 2004, no.4, pp.70-72.

34. Andreiko S.S. Razrabotka parametrov burovzryvnykh rabot dlia effektivnogo initsiirovaniia vybrosov soli i gaza pri peresechenii vybrosoopasnykh geologicheskikh narushenii [Development of parameters for drilling and blasting operations for effective initiation of salt and gas emissions at 
the intersection of emissions-hazardous geological disturbances]. Nauka - proizvodstvu. Perm', Izdatel'stvo Permskogo tekhnicheskogo universiteta, 2005, no.1, pp.52-54.

35. Mal'tsev V.M., Solov'ev V.A. Udarno-impul'snyi metod rascheta parametrov klinovogo vruba [Shock-pulse method for calculating the parameters of a wedge cut]. Vzryvnoe delo, 2008, iss.99/56, pp.20-32.

36. Mal'tsev V.M. Raschet radiusa zony treshchinoobrazovaniia odinochnogo udlinennogo zariada vzryvchatogo veshchestva [Calculation of the radius of the cracking zone of a single elongated explosive charge]. Strategiia $i$ protsessy osvoeniia georesursov. Sbornik nauchnykh trudov. Perm', Izdatel'stvo Gornogo instituta Ural'skogo otdeleniia Rossiiskoi akademii nauk, 2010, pp.220-223.

37. Mal'tsev V.M. Opredelenie dinamicheskoi prochnosti gornykh porod po velichine radiusa zony treshchinovatosti ot vzryva shpurovogo zariada vzryvchatogo veshchestva [Determination of the dynamic strength of rocks in terms of the radius of the zone of fracturing from the explosion of a blast charge of an explosive]. Strategiia $i$ protsessy osvoeniia georesursov. Sbornik nauchnykh trudov. Perm', Izdatel'stvo Gornogo instituta Ural'skogo otdeleniia Rossiiskoi akademii nauk, 2011, pp.262-263.

38. Markov O.I., Beresnev S.P., Petrovskii Iu.B., Andreiko S.S., Mal'tsev V.M. Parametry burovzryvnogo initsiirovaniia vybrosov soli i gaza pri peresechenii vybrosoopasnykh geologicheskikh narushenii [Parameters of drilling and explosive initiation of emissions of salt and gas at crossing of outburst-dangerous geological disturbances]. Gornyi zhurnal, 2010, no.8, pp.75-77.

39. Pravila bezopasnosti pri vzryvnykh rabotakh. Federal'nye normy i pravila $\mathrm{v}$ oblasti promyshlennoi bezopasnosti [Safety rules for blasting operations. Federal rules and regulations in the field of industrial safety]. Moscow, Nauchno-tekhnicheskii tsentr issledovanii problem promyshlennoi bezopasnosti, 2015, series 13, iss.14, 332 p.

40. Spravochnik vzryvnika [Explosion Handbook]. Ed. B.N. Kutuzov. Moscow, Nedra, 1988, 511 p.

\section{Библиографический список}

1. Технология разработки калийных руд В.Г. Зильбершмидт [и др.]. - М.: Недра, 1977.-287 с.

2.Челпанова Е.В., Кошурников Н.С. О возможности разработки маломощных пластов Верхнекамского месторождения калийных солей // Известия вузов. Горный журнал. - 2004. - № 5. - С. 6-9.

3. Шваб Р.Г., Цыганков С.Н., Дешковский В.Н. Перспективы развития калийной промышленности в Республике Беларусь // Горная механика. - 2005. № 3. - С. 84-88.

4. Старков Л.И., Земсков А.Н., Кондрашев П.И. Развитие механизированной разработки калийных руд. Пермь: Изд-во Перм. гос. техн. ун-та, 2007. - 522 с.

5. Семенов В.В., Мальчер М.А., Петров В.П. Российские проходческо-очистные комбайны для добычи калийной руды и каменной соли // Глюкауф. 2007. - № 1. - С. 31-33.

6. Новиков А. Оборудование фирмы DBT для камерно-столбовой системы разработки и проходки выработок // Глюкауф. - 2007. - № 1. - С. 44-49.

7. Смычник А.Д., Морев А.Б., Васько М.В. Системы разработки калийных месторождений: технологические схемы, оборудование, эффективность // Горная механика: науч.-техн. журнал. - 2008. - № 4. - С. 16-28.

8. Бензен X. Калийная промышленность Германии // Глюкауф. - 2009. - № 1. - С. 27-30.

9. Морев А.Б., Смычник А.Д., Казаченко Г.В. Горные машины для калийных рудников. - Минск: Интегралполиграф, 2009. - 544 с.

10. Методическое руководство по ведению горных работ на рудниках ОАО «Сильвинит». - Новосибирск: Наука, 2011. - 487 с.

11. Особенности разработки краевых частей Верхнекамского калийного месторождения / В.А. Соловьев, С.А. Константинова, Д.Н. Алыменко, Л.М. Спехов // Горный журнал. - 2011. - № 12. - С. 41-45.

12. Исаевич А.Г. Снижение запыленности атмосферы рабочей зоны при работе комбайнового комплекса с барабанным исполнительным органом // Стратегия и процессы освоения георесурсов: сб. науч. тр. / ГИ УрО РАН. - Пермь, 2015. Вып. 13. - С. 264-266.

13. Исаевич А.Г. Актуальные вопросы организации проветривания тупиковых выработок // Стратегия и процессы освоения георесурсов: сб. науч. тр. / ГИ УрО РАН. - Пермь, 2016. - Вып. 14. - С. 266-268.

14. Указания по защите рудников от затопления и охране подрабатываемых объектов на Верхнекамском месторождении калийных солей. - СПб.-ПермьБерезники, 2014. - 130 с.

15. Методические рекомендации к «Указаниям по защите рудников от затопления и охране подрабатываемых объектов на Верхнекамском месторождении калийных солей». - СПб.-ПермьБерезники, 2014. - 66 с.

16. Правила безопасности при ведении горных работ и переработке твердых полезных ископаемых: Федеральные нормы и правила в области промышленной безопасности № 32935: утв. 11.12.2013. - М.: ЗАО НТЦ ПБ, 2015. - Вып. 78. - 273 с.

17. Руководство по ведению взрывных работ на калийных рудниках Верхнекамского месторождения. Пермь, 1984. - 195 с.

18. Мальцев В.М., Шабловский В.П. Экспериментальные исследования трещинообразования в соляных породах при взрыве одиночного шпурового заряда ВВ на две обнаженные поверхности // Разработка соляных месторождений: межвуз. сб. науч. тр. - Пермь, 1983. C. $95-98$.

19. Определение параметров комплекта шпуровых зарядов ВВ / В.А. Безматерных, П.А. Лыхин, Н.Н. Лещуков, В.М. Мальцев // Физико-технические проблемы разработки полезных ископаемых. - 1975. - № 6. - С. 69-73.

20. Bandis S.C., Lumsden A.C., Barton N.R. Fundamentals of rock joint deformation // International Journal of Rock Mechanics and Mining Sciences \& 
Geomechanics Abstracts. - 1983. - Vol. 20, № 6. - P. 248 268. DOI: 10.1016/0148-9062(83)90595-8

21. Barton N., Bandis S., Bakhtar K. Strength, deformation and conductivity coupling of rock joints // International Journal of Rock Mechanics and Mining Sciences \& Geomechanics Abstracts. - 1985. - Vol. 22, № 3. - P. 121-140. DOI: 10.1016/0148-9062(85)93227-9

22. Bungum H., Mykkeltveit S., Kvaerna T. Seismic noise in Fennoscandia with emphasis on hight frequencies // Bulletin of the Seismological Society of America. - 1985. Vol. 75, № 6. - P. 1489-1513.

23. Pyrak-Nolte L.J., Myer L.R., Cook N.G.V. Transmission of seismic waves across singl natural fractures // Journal of Geophysical Research: Solid Earth. - 1990. - Vol. 95, № B6. - P. 8617-8638. DOI: $10.1029 / J B 095 i B 06 p 08617$

24. Fracture interface waves / B. Gu, K.T. Nihei, L.R. Myer, L.J. Pyrak-Nolte // Journal of Geophysical Research: Solid Earth. - 1996. - Vol. 191, № 1. - P. 827835. DOI: $10.1029 / 95 J B 02846$

25. Development of a fuzzy model for predicting the penetration rate of tricone rotary blasthole drilling in open pit mines / L. Kricak [et al.] // Journal of the Southern African Institute of Mining and Metallurgy. - 2015. № 115(11). - P. 1065-1071.

26. Drill monitoring results reveal geological conditions in blasthole drilling / P. Hatherly [et al.] // International Journal of Rock Mechanics and Mining Sciences. - 2015. - № 78. - P. 144-154. DOI: 10.1016/j.ijrmms.2015.05.006

27. Servet D. Variation of vertical and horizontal drilling rates depending on some rock properties in the marble quarries // International Journal of Mining Science and Technology. - 2014. - № 24 (2). - P. 269-273. DOI: 10.1016/j.ijmst.2014.01.020

28. Anforderungen an die genauigkeit der zündzeiten elektrischer sprengzünder und versuche zur ermittlung des einflusses des verzögerungsintervalls auf das Sprengergebnis / H.-P. Gerhardt [et al.] // Kali und Steinsalz. - 2013. - Heft 1. - S. 20-29.

29. Behnsen H., Krüger D. Kongressbericht zur 29. Bergtechnischen tagung 2013 in Hannover // Kali und Steinsalz. - 2013. - Heft 2. - S. 10-15.

30. Steinhage M., Triebel R. Arbeitsplatzgrenzwerte: gesundheitsschutz der arbeitnehmer verbessern und die wettbewerbsfähigkeit der industrie wahren // Kali und Steinsalz. - 2014. - Heft 3. - S. 6-13.

31. Лыхин П.А., Мальцев В.М. Нормированный импульс дробления как показатель дробимости горных пород // Физические проблемы разрушения массивов горных пород: сб. докл. междунар. конф. - М.: РАН, 1999. - C. 174-176.

32. Лыхин П.А., Мальцев В.М. Частный закон импульса разрушения горных пород свободным ударом // Известия вузов. Горный журнал. - 2001. № $1 .-$ C. 53-55.

33. Мальцев В.М., Андрейко С.С. Метод расчета цилиндрического вруба с учетом величины коэффициента разрыхления взрываемой породы // Известия вузов. Горный журнал. - 2004. - № 4. - С. 70-72.

34. Андрейко С.С. Разработка параметров буровзрывных работ для эффективного инициирования выбросов соли и газа при пересечении выбросоопасных геологических нарушений // Наука - производству. 2005. - № 1. - С. 52-54.

35. Мальцев В.М., Соловьев В.А. Ударно-импульсный метод расчета параметров клинового вруба // Взрывное дело. - 2008. - Вып. №99/56. - С. 20-32.

36. Мальцев В.М. Расчет радиуса зоны трещинообразования одиночного удлиненного заряда ВВ // Стратегия и процессы освоения георесурсов: сб. науч. тр. Пермь: Изд-во ГИ УрО РАН, 2010. - С. 220-223.

37. Мальцев В.М. Определение динамической прочности горных пород по величине радиуса зоны трещиноватости от взрыва шпурового заряда ВВ // Стратегия и процессы освоения георесурсов: сб. науч. тр. - Пермь: Изд-во ГИ УрО РАН, 2011. C. $262-263$.

38. Параметры буровзрывного инициирования выбросов соли и газа при пересечении выбросоопасных геологических нарушений / О.И. Марков, С.П. Береснев, Ю.Б. Петровский, С.С. Андрейко, В.М. Мальцев // Горный журнал. - 2010. - № 8. - С. 75-77.

39. Правила безопасности при взрывных работах: Федеральные нормы и правила в области промышленной безопасности.- М.: Научно-технический центр исследований проблем промышленной безопасности, 2015. - Сер. 13, вып. 14. - 332 с.

40. Справочник взрывника / под ред. Б.Н. Кутузова. М.: Недра, 1988. - 511 с.

Please cite this article in English as:

Andreyko S.S., Mal'tsev V.M., Anikin V.V., Zhikharev S.Ya. Justification on safe parameters of drilling and blasting mining of sylvinite formations of unconventional thickness together with continuous mining of conventional formations in the mines of Verkhnekamskoe field of potassium and magnesium salts. Perm Journal of Petroleum and Mining Engineering, 2017, vol.16, no.4, pp.357-369. DOI: 10.15593/2224-9923/2017.4.7

Просьба ссылаться на эту статью в русскоязычных источниках следующим образом:

Обоснование безопасных параметров буровзрывной отработки сильвинитовых пластов некондиционной мощности совместно с комбайновой выемкой кондиционных пластов на рудниках Верхнекамского месторождения калийно-магниевых солей / С.С. Андрейко, В.М. Мальцев, В.В. Аникин, С.Я. Жихарев // Вестник Пермского национального исследовательского политехнического университета. Геология. Нефтегазовое и горное дело. - 2017. - Т.16, №4. - С.357-369. DOI: 10.15593/2224-9923/2017.4.7 